\title{
MAKANAN TABU DI BARITO KUALA KALIMANTAN SELATAN
}

\author{
(Taboo Food In Barito Kuala South Kalimantan) \\ Dadang Sukandar ${ }^{1}$
}

\begin{abstract}
Food taboo in Indonesia is still a problem. As consequences, pregnant mother, lactating mother and children do not eat the taboo foods so that it can reduce their food intake and finally it can decrease their nutritional status. The objectives of this study are 1) to identify taboo foods, 2) to identify reasons of taboo food and 3) to improve basic nutrition knowledge through training on food and nutrition. Study was conducted in Barito Kuala South Kalimantan from December 2005 to November 2006. A sample of size 36 households was drawn randomly from household population of size 180. The households population is household farmer who are beneficiary of Special Program for Food Security, Food and Agriculture Organization. Data were analyzed quantitatively and qualitatively and presented in one way table. Results show that groups which had many food taboo were pregnant woman group and lactating mother group. There are 7 taboo foods for pregnant woman and 11 taboo foods for lactating mother. Some taboo foods for pregnant women are ice, twin banana, young coconut, coconut water, young pineapple and fish. Some taboo foods for lactating mother are egg, fresh fish, fish, sugar, salt, jackfruit, fat food, hot food, etc. After attending training, the knowledge on nutrition and food of the farmers increase significantly, therefore it is hoped that their knowledge can reduce their believe of the food taboo.
\end{abstract}

Keywords: taboo food, food intake, nutrition knowledge.

\section{PENDAHULUAN}

\section{Latar Belakang}

Tabu makanan adalah suatu larangan dalam mengonsumsi makanan tertentu karena ada beberapa ancaman atau hukuman bagi orang yang mengonsumsinya. Dalam ancaman ini, terdapat kekuatan supranatural dan mistik yang akan menghukum mereka yang melanggar aturan ini atau tabu (Susanto, 1977)

Dasar dari kebiasaan pangan dicirikan dalam suatu sistem nilai seseorang dalam memilih makanan yang boleh dikonsumsi dan tidak boleh dikonsumsi. Sistem nilai tersebut pada dasarnya berasal dari tiga sumber kebenaran yang dipercayai yaitu

1) Agama dan kepercayaan kepada Tuhan,

2) Adat yang berasal dari nenek moyang,

3) Pengetahuan yang diperoleh dari proses pendidikan formal.

Selain itu, sistem nilai tersebut disosialisasikan dalam keluarga dan dalam pendidikan informal melalui media masa (Nikmawati, 1999).

Tabu makanan di Indonesia masih menjadi masalah karena masih banyak makanan yang seharusnya dikonsumsi tapi masih ditabu-

\footnotetext{
${ }^{1}$ Staf Pengajar Departemen Gizi Masyarakat, Fakultas Ekologi Manusia, IPB
}

kan. Akibat tabu makanan tersebut ibu hamil, ibu menyusui, bayi dan anak-anak tidak berani mengonsumsi makanan tertentu sehingga dapat mengurangi asupan makanan yang pada akhirnya akan menurunkan status gizi mereka.

\section{Tujuan Penelitian}

Penelitian ini bertuj uan untuk:

1. Mengidentifikasi makanan yang ditabukan bagi ibu hamil, ibu menyusui, bayi, balita laki-laki, balita perempuan, laki-laki dewasa, perempuan dewasa dan orang sakit.

2. Mencari alasan-alasan tabu makanan.

3. Memperbaiki pengetahuan gizi para petani melalui pelatihan.

\section{METODE}

\section{Desain, Tempat dan Waktu Penelitian}

Penelitian ini menggunakan desain crosssectional dengan cara survai. Penelitian dilakukan di Barito Kuala, Provinsi Kalimantan Selatan. Penelitian dilakukan dari Desember 2005 sampai November 2006.

\section{Prosedur Penarikan Contoh}

Pada tahun 2000, FAO dan Departemen Pertanian memilih Barito Kuala sebagai tempat 
untuk melakukan kegiatan pemberdayaan petani melalui proyek yang bernama Special Program for Food Security (SPFS). Barito Kuala dipilih karena merupakan daerah pasang surut. Petani yang diberdayakan melalui proyek SPFS tersebut adalah petani yang merupakan anggota dari kelompok tani. Para petani tersebut memiliki aset pertanian seperti sawah, kolam ikan, ladang dan pekarangan. Ada 6 kelompok tani di Barito Kuala yang mendapat bantuan proyek SPFS tersebut.

Selanjutnya keseluruhan petani tersebut didefinisikan sebagai populasi yang jumlahnya sebanyak 180 keluarga. Dari populasi tersebut ditarik sampel melalui teknik penarikan contoh acak berlapis, dalam hal ini kelompok tani berdiri sebagi lapis. Penentuan ukuran sampel didasarkan pada penarikan contoh acak sederhana dengan formula (Cochran, 1982) sebagai berikut:

$$
n=\frac{n_{o}}{1+\frac{n_{o}-1}{N}}
$$

keterangan:

$$
\begin{aligned}
n_{o}= & \frac{p(1-p) t_{\alpha / 2}^{2}(v)}{d^{2}} \\
n \quad= & \text { ukuran sampel rumahtangga } \\
\mathrm{P} \quad & \text { penduga proporsi keluarga yang in- } \\
& \text { take energi dan proteinnya di ba- } \\
& \text { wah } 70 \%(\text { rendah) } \\
= & \text { keakurasian mutlak perbedaan an- } \\
& \text { tara parameter } \mathrm{p} \text { dan } \mathrm{p} \\
\mathrm{d} \quad & \text { suatu nilai sehingga } \mathrm{P}\left(-\mathrm{t}_{\alpha / 2}(\mathrm{v})<\mathrm{t}<\right. \\
& \left.\mathrm{t}_{\alpha / 2}(\mathrm{v})\right)=1-\alpha, \mathrm{t} \text { adalah peubah acak } \\
& \text { fungsi kepekatan t-student dengan } \\
& \text { derajat bebas } \mathrm{v} \\
\mathrm{t}_{\alpha / 2}(\mathrm{v}) & \\
\mathrm{N} \quad= & \text { ukuran populasi }
\end{aligned}
$$

Dasar untuk menentukan ukuran contoh adalah penduga proporsi keluarga yang konsumsi energi dan proteinnya rendah. Agar contoh serupa dengan populasinya, $\alpha$ dan $d$ yang dipilih harus rendah. Untuk menentukan n, $\alpha=0.05$ dan $d=0.053958$ dipilih karena cukup baik

Ali Khomsan et al. (2005) menunjukkan bahwa proporsi keluarga yang konsumsi energi dan proteinnya di bawah $70 \%$ adalah $p>0.4$ oleh karena itu $p=0.5$ dipilih untuk menduga ragam $p(1-p)$. Substitusi $\alpha=0.05, d=0.053958$, $p=0.4$ and $\mathrm{N}=180$ ke dalam formula menghasilkan ukuran contoh $\mathrm{n}=36$.

Penarikan contoh acak berlapis dengan

\begin{tabular}{|c|c|c|}
\hline Kelompok Tani & $\mathbf{N}_{\mathbf{i}}$ & $\mathbf{n}_{\mathbf{i}}$ \\
\hline 1. Usaha Bersama & 30 & 6 \\
\hline 2. Kasturi Raya & 30 & 6 \\
\hline 3. Karya Membangun & 30 & 6 \\
\hline 4. Karya Bakti & 30 & 6 \\
\hline 5. Sepakat & 30 & 6 \\
\hline 6. Karya Muda & 30 & 6 \\
\hline Jumlah & 180 & 36 \\
\hline
\end{tabular}
alokasi proporsional digunakan untuk menentu- kan ukuran contoh dari tiap kelompok tani. Ukuran contoh dari kelompok tani ditentukan sebagai berikut:

$$
n_{i}=\frac{N_{i}}{N} n
$$

keterangan:

$$
\begin{aligned}
& \mathrm{n}_{\mathrm{i}}=\text { ukuran contoh kelompok tani ke-i } \\
& \mathrm{N}_{\mathrm{i}}=\text { ukuran kelompok tani ke-i } \\
& \mathrm{N}=\text { ukuran populasi } \\
& \mathrm{n}
\end{aligned}
$$

Dengan menggunakan formula tersebut, ukuran contoh untuk semua kelompok tani didaftarkan pada Tabel 1.

Tabel 1. Daftar Ukuran Contoh Kelompok Tani $\left(n_{\mathrm{i}}\right)$

\section{Lenis dan Cara Pengumpulan Data}

Data yang dikumpulkan mencakup data nama anggota keluarga, jenis kelamin; umur; fisiologi; nama-nama makanan yang ditabukan; nama-nama makanan yang ditabukan bagi: bayi, laki-laki dewasa, perempuan dewasa, balita laki-laki, balita perempuan, perempuan hamil, perempuan menyusui, dan orang sakit; dan alasan tabu.

\section{Pelatihan}

Pelatihan dilakukan dalam dua tahap. Tahap pertama dilakukan pada para pelatih yang berasal dari Dinas Kesehatan Barito Kuala. Pelatihan tahap pertama dilakukan pada bulan Maret 2006 selama 7 hari. Materi yang dilatihkan mencakup pengetahuan gizi dasar, keamanan pangan, cara mengolah makanan, sanitasi dan higiene. Tahap kedua adalah pelatihan terhadap para petani yang dilakukan oleh para pelatih yang telah dilatih. Pelatihan tahap kedua dilakukan dari bulan Juni sampai Agustus 2006. Pelatihan diawali dengan pre test lalu diakhiri post test untuk tiap materi.

\section{Pengolahan dan Analisis Data}

Pengolahan data mencakup editing, penyusunan struktur file, data entry, editing da- 
ta pada file komputer dan sorting. Pengolahan data dilakukan dengan menggunakan MS Office Excel for Windows.

Analisis data mencakup tabulasi data menurut kelompok orang, nama makanan yang ditabukan dan alasan tabu. Komputasi dilakukan untuk menduga rata-rata, simpangan ba$\mathrm{ku}$, nilai minimum dan maksimum untuk pengetahuan gizi awal dan akhir, hasilnya disaj ikan dalam tabel. Analisis data dilakukan dengan menggunakan progam Statistical Analysis System (SAS) (1985).

\section{HASIL DAN PEMBAHASAN}

\section{Lumlah Anggota Keluarga}

Rata-rata jumlah anggota keluarga tergolong sedang yaitu sebesar 4.9 orang per keluarga seperti dapat dilihat pada Tabel 2. Keragaman jumlah anggota keluarga tergolong sedang, yaitu ditunjukkan dengan simpangan baku sebesar 2.0 orang. J umlah anggota keluarga minimum 2 orang dan maksiumum 11 orang.

Tabel 2. Statistik J umlah Anggota Keluarga

\begin{tabular}{|l|c|}
\hline Statistik & J umlah Anggota keluarga \\
\hline mean & 4.9 \\
\hline std & 2.0 \\
\hline $\min$ & 2.0 \\
\hline $\max$ & 11.0 \\
\hline
\end{tabular}

\section{Pendidikan dan Umur Suami Istri}

Rata-rata umur suami istri tergolong pertengahan. Rata-rata umur istri adalah 39 tahun, sedangkan suami adalah 45 tahun. Umur istri berkisar antara 20 sampai 65 tahun, sedangkan umur suami berkisar antara 23 sampai 78 tahun seperti dapat dilihat pada Tabel 2.

Rata-rata pendidikan suami istri tergolong rendah. Rata-rata pendidikan istri adalah 5. 6 tahun atau setara SD, sedangkan suami adalah 5.7 tahun atau juga setara SD. Pendidikan suami dan istri berkisar dari 0 sampai 16 tahun seperti dapat dilihat pada Tabel 3.

Tabel 3. Statistik Umur dan Pendidikan SuamiIstri

\begin{tabular}{|l|c|c|c|c|}
\hline \multirow{2}{*}{$\begin{array}{c}\text { Statistik } \\
\text { (tahun) }\end{array}$} & \multicolumn{2}{|c|}{ Istri } & \multicolumn{2}{c|}{ Suami } \\
\cline { 2 - 5 } & Umur & Pddk & Umur & Pddk \\
\hline mean & 39 & 4.9 & 45 & 6.3 \\
\hline std & 10 & 3.6 & 11 & 3.6 \\
\hline min & 20 & 0 & 25 & 0 \\
\hline max & 65 & 16 & 70 & 16 \\
\hline
\end{tabular}

Catatan: Pddk = Pendidikan

\section{Makanan Tabu bagi lbu Hamil}

Makanan yang ditabukan bagi ibu hamil sangat banyak yaitu ada 7 makanan. Daftar makanan serta alasan tabu bagi makanan tersebut dapat dilihat pasa Tabel 4. Alasan tabu semua berkaitan dengan kelahiran, misalnya jika makan es atau pisang kembar atau kelapa muda atau ikan maka anak yang akan dilahirkan akan besar dan sekaligus sakit. Apabila ibu hamil makan nenas muda maka ibu hamil tersebut bisa keguguran. Alasan yang diberikan oleh responden tersebut tidak ada yang logis.

Tabel 4. Daftar Makanan Tabu Bagi Ibu Hamil

\begin{tabular}{|c|l|l|}
\hline No & \multicolumn{1}{|c|}{ Makanan } & \multicolumn{1}{c|}{ Alasan Tabu } \\
\hline 1 & Es & Anak dilahirkan besar dan sakit \\
\hline 2 & Pisang kembar & Anak dilahirkan besar dan sakit \\
\hline 3 & Kelapa muda & Anak dilahirkan besar dan sakit \\
\hline 4 & Air kelapa & Anak dilahirkan besar \\
\hline 5 & Nenas muda & Keguguran \\
\hline 6 & Ikan & Anak dilahirkan besar dan sakit \\
\hline 7 & Ikan tauman & Ibu bisa sakit \\
\hline
\end{tabular}

\section{Makanan Tabu bagi lbu menyusui}

Makanan yang ditabukan bagi ibu menyusui ada sebanyak 11 makanan. Daftar makanan serta alasan tabu dapat dilihat pada Tabel 5. Telur dan ikan sangat baik baik ibu menyusui karena merupakan sumber protein namun sayangnya ditabukan. Hal ini jelas akan mempengaruhi intik protein karena ibu menyusui tersebut tidak berani mengonsumsi makanan tersebut.

Tabel 5. Daftar Makanan yang Ditabukan Bagi Ibu Menyusui

\begin{tabular}{|c|c|c|}
\hline No & Makanan & Alasan \\
\hline 1 & Telur & Akan hamil lagi \\
\hline \multirow[t]{2}{*}{2} & \multirow[t]{2}{*}{ Ikan Segar } & $\begin{array}{l}\text { Pendarahan setelah } 40 \text { hari melahirkan } \\
\text { dan urin anak bau }\end{array}$ \\
\hline & & Demam \\
\hline 3 & Ikan & Akan timbul bintik merah di kulit anak \\
\hline \multirow{2}{*}{4} & \multirow{2}{*}{ Gula } & Demam \\
\hline & & Akan timbul bintik merah di kulit anak \\
\hline \multirow{2}{*}{5} & \multirow{2}{*}{ Garam } & Demam \\
\hline & & Akan timbul bintik merah di kulit anak \\
\hline 6 & Ikan kalui & Keracunan \\
\hline 7 & Nangka & Gatal \\
\hline 8 & $\begin{array}{l}\text { Makanan } \\
\text { berlemak }\end{array}$ & $\begin{array}{l}\text { Pendarahan setelah } 40 \text { hari melahirkan } \\
\text { dan urin anak bau }\end{array}$ \\
\hline \multirow[t]{2}{*}{9} & \multirow{2}{*}{$\begin{array}{l}\text { Makanan } \\
\text { pedas }\end{array}$} & $\begin{array}{l}\text { Pendarahan setelah } 40 \text { hari melahirkan } \\
\text { dan urin anak bau }\end{array}$ \\
\hline & & Susu ibu akan asam dan anak akan diare \\
\hline 10 & Santan & Ibu bisa sakit \\
\hline \multirow{2}{*}{11} & \multirow{2}{*}{$\begin{array}{l}\text { Makanan } \\
\text { asam }\end{array}$} & Susu ibu akan asam dan anak akan diare \\
\hline & & Akan timbul bintik merah di kulit anak \\
\hline
\end{tabular}




\section{Makanan Tabu bagi Bayi dan Balita}

Makanan yang ditabukan untuk bayi hanya dua macam yaitu ikan tauman dan ikan gabus. Alasannya adalah ikan tersebut dapat menyebabkan anak sakit. Untuk bayi nampaknya tidak menjadi masalah karena hanya ada dua makanan saja yang ditabukan.

Makanan yang ditabukan bagi balita perempuan hanya telur saja. Bagi balita laki-laki telur tidak ditabukan. Walaupun hanya satu macam namun telur merupakan sumber protein yang mudah tersedia dan harganya terjangkau. Oleh karenanya perlu upaya-upaya untuk menyadarkan masyarakat untuk menghilangkan tabu tersebut.

\section{Makanan Tabu bagi Perempuan Dewasa}

Makanan tabu bagi perempuan dewasa hanya ditemukan dua macam yaitu telur dan pisang kembar. Menurut kepercayaan mereka makanan tersebut suatu saat nanti dapat memberikan bayi kembar. Kepercayaan ini sangat merugikan bagi perempuan dewasa karena sebagai calon ibu, perempuan perlu mengonsumsi telur yang mengandung tinggi protein dan terjangkau.

\section{Makanan Tabu bagi Orang Sakit}

Makanan yang ditabukan bagi orang sakit ada 5 macam. Makanan tersebut adalah telur rebus, cabe, pedas, nenas dan pepaya. Mereka percaya, jika orang sakit makan cabe, pedas, nenas atau pepaya maka orang sakit tersebut akan demam. Sementara jika orang sakit tersebut makan telur rebus maka dipercaya orang sakit tersebut akan terkena penyakit kanker. Alasan tabu yang lain yaitu orang sakit akan menderita tekanan darah tinggi jika mengonsumsi daging.

Tabel 6. Daftar Makanan Tabu Bagi Orang Sakit

\begin{tabular}{|c|l|l|}
\hline No & Makanan & \multicolumn{1}{|c|}{ Alasan Tabu } \\
\hline 1 & Telur rebus & Menderita Kanker \\
\hline 2 & Cabe & Demam \\
\hline 3 & Pedas & Demam \\
\hline 4 & Nenas & Demam \\
\hline 5 & Pepaya & Demam \\
\hline 6 & Daging & Tekanan Darah tinggi \\
\hline
\end{tabular}

\section{Hasil Pelatihan}

Materi pengetahuan gizi dasar yang dilatihkan mencakup jenis-jenis pangan sumber zat tenaga, sumber zat pembangun, sumber zat pengatur. Fungsi, akibat kekurangan, akiakibat kelebihan dari karbohidrat, protein, vitamin dan mineral. Hasil pre test menunjukkan bahwa rata-rata pengetahuan responden sebesar 5.5 dalam skala 0-10 dengan simpangan baku sebesar 1.8, nilai minimum 1 dan maksimum 10. Setelah pelatihan, hasil post test menunjukkan adanya peningkatan dengan rata-rata 7.0 atau meningkat sebesar 1.5. Peningkatan ini diharapkan akan meningkatkan kesadaran ibu rumah tangga dan anggota keluarga akan pentingnya zat gizi yang terkandung dalam makanan untuk memperbaiki status gizi mereka. Diharapkan pengetahuan gizi tersebut dapat mengurangi kepercayaan akan tabu makanan yang merugikan gizi dan kesehatan mereka.

Tabel 7. Hasil Pre- dan Post-Test Pelatihan Pengetahuan Gizi Dasar

\begin{tabular}{|l|c|c|c|}
\hline \multicolumn{1}{|c|}{ Test } & Pre-test & Post-test & Delta \\
\hline mean & 5.5 & 7.0 & 1.5 \\
\hline std & 1.8 & 1.5 & 1.7 \\
\hline $\min$ & 2.0 & 3.0 & -2 \\
\hline $\max$ & 9 & 10 & 7 \\
\hline
\end{tabular}

\section{KESIMPULAN DAN SARAN}

\section{Kesimpulan}

1. Masih cukup banyak makanan yang ditabukan bagi ibu hamil dan ibu menyusui. J umlah makanan yang ditabukan bagi ibu hamil sebanyak 7 jenis dan bagi ibu menyusui sebanyak 11 jenis. Makanan tersebut mencakup pangan sumber zat tenaga, pembangun dan pengatur.

2. Hanya ditemukan dua jenis makanan yang ditabukan bagi bayi yaitu ikan tauman dan ikan gabus.

3. Makanan yang ditabukan untuk balita hanya satu macam yaitu telur. Makanan ini hanya tabu bagi balita perempuan. Tidak ditemukan makanan yang ditabukan bagi balita laki-laki.

4. Bagi orang dewasa, makanan yang ditabukan hanya bagi perempuan dewasa, bagi laki-laki dewasa tidak ditemukan makanan yang ditabukan. Makanan tersebut adalah telur dan pisang kembar. Makanan tersebut dipercaya akan menyebabkan melahirkan dengan bayi kembar.

5. Makanan yang ditabukan untuk orang sakit ditemukan sebanyak lima macam yang terdiri atas telur rebus, cabe, pedas, nanas, papaya dan daging. Telur rebus dipercaya dapat menyebabkan kanker, daging dipercaya dapat menyebabkan tekanan darah 
tinggi dan yang lainnya dipercaya dapat menyebabkan demam.

6. Pelatihan telah dapat meningkatkan pengetahuan gizi dasar sebesar 1.5 yaitu dari 5.5 menjadi 7.0.

\section{Saran}

Upaya penurunan kepercayaan akan tabu makanan masih sangat perlu dilakukan khususnya makanan tabu bagi hamil dan ibu menyusui. Upaya ini dapat dilakukan oleh para petugas Dinas Kesehatan dan kader-kader posyandu secara terus-menerus.

\section{DAFTAR PUSTAKA}

Cochran WG. 1982. Sampling Technique. John Wiley $\&$ Sons.
Nikmawati EE. 1999. Pola Konsumsi Pangan, Kecukupan dan Status Gizi yang berhubungan dengan Kebiasaan Makan Singkong di Masyarakat Cireundeu, Cimahi, Jawa Barat. Thesis Program Pasca Sarjana, IPB, Bogor.

SAS Institute Inc. 1985. Procedure Guide for Personal Computer, Version 6 Edition. Cary, North Carolina.

Suhardjo 1989. Sosio-budaya Gizi. Departemen Pendidikan dan Kebudayaan. Direktorat Pendidikan Tinggi. Pusat Antar Perguruan Tinggi untuk Makanan dan Gizi, IPB, Bogor.

Susanto D. 1991. Fungsi-fungsi Sosio-Budaya Makanan. Majalah Pangan No 9, J uli, 5156. 